\title{
EXECUTIVE STOCK OPTION PLANS: UJI PENGELOLAAN LABA SELAMA VESTING PERIOD
}

\author{
Nur Fadjrih Asyik \\ nurfadjrih2003@yahoo.com
}

Sekolah Tinggi Ilmu Ekonomi Indonesia (STIESIA) Surabaya

\begin{abstract}
This study examine earnings management behavior related to compensation in the form of stock options during implementation of the grant program (vesting period). The study also examine and identify the differences in behavior during the execution of stock options. Companies as a sample in this study is a company listed in the Indonesia Stock Exchange, which has adopted the Executive Stock Option Plan and restricted to the companies that publish financial statements as of December 31 for the year 2007 to 2009. Final sample of this research into as many as 21 sample companies and the number of observations are 63 observational studies. The result of testing $H_{1}$ shows that the more stock options offered to employees, the managers more motivated to manage earnings down prior to offering stock options. The results are consistent with previous studies of the behavior of managers who expect the share price decline before the date of grant, so the manager to pay compensation for stock options with a relatively cheap price. The results of testing $\mathrm{H}_{2 a}$ and $\mathrm{H}_{2 b}$ show that the more stock options offered to employees, the managers more motivated to manage earnings upward after offering stock options. Results show that an early stage implementation of executive stock option plans, executives trend to behave increasing income until vesting period final.
\end{abstract}

Keyword: Executive Stock Option Plan, Earning Management, Grant Date, and Vesting Period.

\section{PENDAHULUAN}

Teori entitas (entity theory) memandang perusahaan sebagai suatu entitas yang terpisah dari pemilik dan krediturnya. Berdasarkan pandangan teori tersebut, manajemen terpisah dari pemilik perusahaan. Manajemen memperoleh kepercayaan dari pemilik untuk mengelola perusahaan, dan atas jasa yang diberikan, para manajer memperoleh kompensasi (Jensen dan Meckling, 1976). Dua pihak yang melakukan kontrak dalam agency theory (prinsipal-agen) biasanya berada dalam situasi ketidakseimbangan informasi (asymmetrical information), artinya bahwa agen mempunyai lebih banyak 
informasi mengenai perusahaan daripada prinsipal dan diasumsikan bahwa individuindividu bertindak untuk memaksimalkan kepentingan dirinya sendiri. Masing-masing individu diasumsikan semata-mata termotivasi oleh kepentingan sendiri sehingga menimbulkan konflik kepentingan di antara prinsipal dan agen (Scott, 2009). Teori agensi menyarankan bahwa dengan mempertimbangkan karakteristik perusahaan dan lingkungan organisasional, perusahaan dapat mengadopsi sistem pengendalian korporat tertentu untuk mengeliminasi biaya agensi (Machfoedz, 2002). Sesuai dengan teori agensi, corporate board merupakan mekanisme internal governance yang penting.

Kompensasi merupakan nilai jasa yang diberikan pemilik perusahaan kepada manajemen (Jensen dan Meckling, 1976). Adanya program kompensasi manajemen diharapkan dapat mengurangi konflik kepentingan antara prinsipal dan agennya. Kompensasi ekuitas telah menjadi salah satu bentuk utama pembayaran manajerial, secara khusus bentuk insentif ekuitas tersebut adalah opsi saham eksekutif. Pemberian kompensasi opsi saham akan menyebabkan dilution effect.

Masalah utama penelitian ini adalah apakah eksekutif penerima hibah opsi saham cenderung berperilaku melakukan pengelolaan laba selama pelaksanaan hibah (vesting period). Perilaku pengelolaan laba dilakukan karena hampir seluruh opsi dihibahkan dengan harga pengambilan (exercise price) sama dengan harga saham pada tanggal hibah. Karena untung (gain) dari opsi saham tergantung pada perbedaan antara harga pengambilan yang ditentukan pada tanggal hibah dengan harga pasar pada tanggal pengambilan, maka kondisi tersebut memungkinkan adanya perilaku oportunistik dari eksekutif. Perilaku tersebut semakin terdukung jika magnituda opsi yang diterima relatif banyak. Berdasarkan hal tersebut, manajer sangat berkepentingan terhadap pergerakan harga saham.

Penelitian empiris tentang reaksi pasar menunjukkan bahwa harga saham bergerak sebagai reaksi investor terhadap informasi akuntansi yang dilaporkan perusahaan, salah satu di antaranya adalah laba (Ball dan Brown, 1968). Secara empiris, laba digunakan sebagai alat ukur kinerja manajemen yang lebih baik daripada aliran kas, karena dapat mengurangi masalah ketepatwaktuan dan kesalahan menandingkan (matching) (Dechow et al., 1995). Laba sebagai pengukur kinerja sekaligus alat dalam pengambilan keputusan memiliki fleksibilitas yang diberikan oleh prinsip akuntansi berterima umum (PABU). Selain fleksibilitas, manajemen juga memiliki beberapa kebijakan terhadap pengakuan akrual dalam laba sehingga sulit bagi pemakai memperkirakan reliabilitas dari signal yang dihasilkan manajemen (Scott, 2009). Di samping itu, adanya ketidakselarasan (missalignment) antara manajer dan pemegang saham (shareholders) mendorong manajer untuk menggunakan fleksibilitas yang diberikan PABU untuk mengelola laba secara oportunistik yang menyebabkan distorsi atas laba yang dilaporkan (Watts dan Zimmerman, 1986). 
Laba sebagai alat mengukur kinerja perusahaan memuat informasi berkaitan dengan kewajiban manajemen atas tanggung jawabnya dalam pengelolaan sumber daya yang dipercayakan kepada mereka. Laba tersebut sering dijadikan dasar untuk mengambil keputusan dan menyusun kontrak oleh berbagai pihak yang berkepentingan, di antaranya digunakan sebagai salah satu dasar memberikan bonus kepada manajer. Selain itu, laba juga digunakan sebagai salah satu kriteria penilaian kinerja. Perusahaan dengan laba yang rendah relatif dianggap lebih buruk kinerjanya dibandingkan dengan perusahaan yang labanya tinggi. Dengan demikian, wajar jika manajer memanfaatkan peluang untuk memainkan angka laba dalam rangka mempengaruhi hasil akhir dari berbagai keputusan. Secara empiris terbukti bahwa manajer berusaha untuk memaksimumkan utilitas manajemen yang berkaitan dengan rencana kompensasi dengan mengelola angka akrual (Healy, 1985; Holthausen et al., 1995; Gaver et al., 1995).

Eksekutif memiliki dorongan menurunkan harga pasar saham sebelum tanggal hibah dalam rangka mengurangi harga pengambilan opsi (Chauvin dan Shenoy, 2000; Balsam et al., 2003) sehingga eksekutif membayar murah apabila eksekutif mengambil hak atas opsi saham tersebut. Dengan demikian, perilaku manajemen untuk mengelola laba dapat berbentuk laba menurun (income decreasing). Selanjutnya, setelah tanggal hibah, eksekutif berkepentingan terhadap peningkatan laba, dengan harapan gain yang diperoleh juga semakin besar.

Tujuan penelitian ini adalah untuk menguji perilaku pengelolaan laba berkaitan dengan kompensasi dalam bentuk opsi saham selama pelaksanaan program hibah (vesting period). Penelitian ini juga berusaha menguji dan mengidentifikasi perbedaan perilaku selama pelaksanaan opsi saham eksekutif tersebut. Manajer dapat mempengaruhi harga saham perusahaan dengan mengelola kinerja yang dilaporkan (Subramanyam, 1996). Chauvin dan Shenoy (2000) menguji cumulative abnormal return (CAR) sebelum pelaksanaan penawaran opsi saham. Hasil pengujian menunjukkan adanya CAR yang menurun secara mencolok dalam 10 hari sebelum penghibahan opsi saham. Yermack (1997) menguji penyaatan (timing) penawaran opsi saham pada perusahaan Fortune dari tahun 1992 sampai 1994. Hasil penelitian menunjukkan bahwa harga saham naik secara mencolok sesudah penawaran opsi saham. Hal tersebut mengindikasi adanya asosiasi antara saat penawaran opsi saham dengan gerakan harga saham perusahaan. Karena opsi yang ditawarkan tidak dapat diambil dalam perioda tanggal hibah, perusahaan menggunakan akrual yang menurunkan laba dalam rangka membentuk sebuah cadangan untuk perioda ketika opsi bisa diambil. Selanjutnya sesudah opsi diambil, perusahaan akan menggunakan akrual yang meningkatkan laba. Untuk memaksimumkan nilai opsi, pemilihan akrual optimal tergantung pada nilai opsi yang diambil saat ini dan nilai diskontoan opsi yang diambil masa mendatang.

Penelitian ini diharapkan dapat memberi manfaat secara teoretis dan praktis. Dari segi teoretis, penelitian ini memberi kontribusi pada penelitian akuntansi dengan 
mengidentifikasi perilaku eksekutif melakukan pengelolaan laba atas penerapan program kompensasi opsi saham. Hasil penelitian ini diharapkan bermanfaat dalam pengembangan ilmu yang akan memperkuat model hubungan prinsipal dan agen (teori agensi), terutama yang berkaitan dengan konflik kepentingan antara manajer sebagai agen dan pemilik dana sebagai prinsipal (Healy dan Palepu, 1993). Dari segi praktis, hasil penelitian dapat digunakan sebagai pedoman bagi perusahaan terutama pemegang saham dalam mengambil keputusan penerapan program opsi saham eksekutif.

\section{RERANGKA TEORETIS}

\section{Tinjauan Umum Program Opsi Saham Eksekutif}

Program kompensasi dimaksudkan untuk mendorong manajemen agar dapat memaksimumkan nilai perusahaan yang direfleksi dengan perolehan laba atau harga saham (Adli, 2001). Di samping itu, program kompensasi manajemen dimaksudkan pula untuk mengurangi konflik kepentingan antara pemilik dan manajemen, karena upaya maksimisasi nilai perusahaan (melalui program kompensasi) berarti juga upaya meningkatkan kesejahteraan manajemen (Misnen, 2004). Selanjutnya berkaitan dengan hasil (outcome) atau kinerja (performance) yang diperoleh manajemen, maka desain paket pembayaran para eksekutif korporat (corporate executive pay package) dapat ditetapkan dalam usaha mengurangi biaya agensi (agency cost) antara pemegang saham dan manajer. Yermack (1997) menyatakan bahwa kontrak kompensasi memotivasi para eksekutif perusahaan, sehingga program kompensasi eksekutif seharusnya cukup kompetitif untuk menarik dan mempertahankan manajer berkualitas tinggi, menghubungkan bonus dengan kinerja, dan mampu mengembangkan iklim berorientasi kinerja dalam perusahaan dengan memberikan imbalan terhadap kinerja yang dinilai baik. Sistem kompensasi tersebut di antaranya: (1) gaji, (2) bonus berupa berupa uang atau saham yang dikaitkan dengan kinerja jangka pendek perusahaan, misalnya pertumbuhan laba, penjualan tahunan, dan pertumbuhan economic value added, dan (3) opsi atau hak membeli saham untuk menghargai eksekutif atas kinerja jangka panjang perusahaan. Opsi saham eksekutif memotivasi eksekutif untuk bekerja dengan lebih keras dan meningkatkan kinerja perusahaan secara loyal (Libby dan Seybert, 2009).

Opsi saham merupakan kontrak yang memberi hak kepada eksekutif perusahaan (eksekutif) untuk membeli kembali saham perusahaan dalam jangka waktu tertentu dengan harga tertentu pula. Pada umumnya harga pengambilan di bawah harga pasar saham yang bersangkutan (Jiraporn et al., 2008). Kebijakan ini disebut dengan program opsi saham eksekutif. Opsi saham ini biasanya digunakan sebagai sarana untuk meningkatkan loyalitas dan motivasi eksekutif dengan menjadikan mereka pemilik perusahaan dan untuk menambah penghasilan eksekutif (sebagai kompensasi tambahan). Banyaknya saham yang dapat dibeli dan harga opsi di masa mendatang bergantung pada pertumbuhan perusahaan dan perubahan harga saham. 
Opsi saham eksekutif adalah salah satu program untuk kepentingan eksekutif (execitive benefits) yang paling populer karena memberi kesempatan kepada eksekutif untuk ikut mengambil bagian dalam kesuksesan perusahaan (Yu, 2008). Tujuan program opsi saham eksekutif baik dari sisi perusahaan maupun sisi eksekutif disajikan pada tabel 1 berikut:

Tabel 1

Tujuan Program Opsi Saham Eksekutif

\begin{tabular}{ll}
\hline \hline \multicolumn{1}{c}{ Tujuan (Sisi Perusahaan) } & \multicolumn{1}{c}{ Tujuan (Sisi Eksekutif) } \\
\hline Memberi insentif yang menarik yang akan & Memberi kesempatan kepada eksekutif \\
membantu merekrut eksekutif terampil & untuk ikut menikmati pertumbuhan \\
dan mempertahankan eksekutif lama & perusahaan tanpa risiko apapun. \\
tanpa menghabiskan uang tunai yang & $\rightarrow$ Eksekutif tidak disyaratkan untuk \\
berharga. & melakukan apapun jika opsi terbukti \\
& tidak berharga. \\
& $\rightarrow$ Apabila harga saham naik, eksekutif \\
& siap menerima keuntungan tanpa \\
& menangung risiko yang biasanya ada \\
& dalam setiap investasi. \\
\hline
\end{tabular}

Sumber: Sesil et al. (2002)

\section{Tinjauan Akuntansi Program Opsi Saham Eksekutif}

Akuntansi opsi saham eksekutif telah menjadi isu yang kontroversial sejak akhir tahun 1980-an dan menjadi fokus perdebatan nasional dan internasional akhir-akhir ini di antara penyusun standar, manajer, investor, dan akademisi. Mayoritas perusahaan menentang mengakui jumlah rupiah opsi saham di dalam laporan laba rugi. Tetapi, dimulai bulan Juli 2002 perusahaan mulai mengumumkan secara sukarela keputusan mereka untuk mengakui jumlah rupiah opsi saham. Ini merupakan perioda ketika atmosfer pelaporan keuangan mengandung kecurigaan karena standar akuntansi melibatkan Enron dan Worldcom. Hal tersebut merupakan saat yang tepat bagi perusahaan untuk berusaha dan mensignal kejujuran (honesty) mereka dalam pelaporan keuangan. Manajer perusahaan mengambil keuntungan dari kondisi tersebut dan memutuskan mengakui jumlah rupiah opsi saham.

Standar akuntansi akhir-akhir ini mengharuskan perusahaan mengakui beberapa tipe kompensasi di antaranya gaji, bonus kas, dan nilai hibah opsi, tetapi mengijinkan kebijaksanaan perusahaan apakah mengakui jumlah rupiah opsi saham (Ikatan Akuntan Indonesia, 2009). Bagaimanapun informasi mengenai hibah opsi saham baik jumlah rupiah maupun dampak per saham opsi saham pada laba bersih tersedia di dalam catatan atas laporan keuangan, mengikuti adopsi SFAS 123 tahun 1995. FASB juga akhir-akhir ini mengemukakan isu tentang apakah memandatkan mengakui jumlah rupiah opsi saham dalam agendanya. 
Peran akuntansi dalam kaitannya dengan penerapan program opsi saham eksekutif secara garis besar disajikan pada gambar 1 berikut:

\begin{tabular}{|c|c|}
\hline 1972 & \\
\hline $\begin{array}{c}\text { Accounting Principle } \\
\text { Board (APB) menerbitkan } \\
\text { Opinion No. 25: } \\
\text { "Accounting for Stock } \\
\text { Issued to Employee" }\end{array}$ & $\begin{array}{l}\text { Fokus utama perdebatan Opinion No. 25: Perlakuan } \\
\text { akuntansi tidak konsisten untuk transaksi yang sama. } \\
\text { Opinion No. } 25 \text { mengharuskan pengakuan biaya } \\
\text { kompensasi untuk opsi saham dengan variable exercise } \\
\text { prices dan stock appreciation rights. Untuk fixed option } \\
\text { (exercise price dan jml saham adalah tetap pada grant } \\
\text { date) tidak terdapat biaya kompensasi yang diakui } \rightarrow \text { jika } \\
\text { exercise price } \geq \text { market price pada grant date }\end{array}$ \\
\hline
\end{tabular}

\begin{tabular}{|c|c|}
\hline Antara 1985-1988 & \\
\hline $\begin{array}{c}\text { FASB melakukan } \\
\text { penelitian tentang } \\
\text { penentuan model stock } \\
\text { option terhadap program } \\
\text { opsi saham }\end{array}$ & $\begin{array}{l}\text { Perundingan board dilakukan setiap minggu di "Action } \\
\text { Alert". > } 200 \text { surat diterima dan tidak setuju terhadap } \\
\text { gambaran FASB di Action Alert. Board sepakat opsi } \\
\text { saham eksekutif diakui sebagai "Biaya Kompensasi". }\end{array}$ \\
\hline 30 Juni 1993 & \\
\hline $\begin{array}{l}\text { FASB menerbitkan } \\
\text { "Exposure Draft" }\end{array}$ & $\begin{array}{l}\text { Fair value dari stock option seharusnya diukur pada saat } \\
\text { option di granted. Jadi pada grant date, diakui: } \\
\text { Asset (prepaid compensation } \rightarrow \\
\text { = fair value dari option) } \\
\text { Equity (outstanding option) } \mathrm{xx} \\
\text { (Aset di expense terhadap earning selama vesting } \\
\text { period) }\end{array}$ \\
\hline 23 Okt 1995 & \\
\hline $\begin{array}{l}\text { FASB menerbitkan SFAS } \\
\text { No. 123: Accounting for } \\
\text { Stock-Based } \\
\text { Compensation }\end{array}$ & $\begin{array}{l}\text { Standar mendukung perush mengakui biaya opsi saham } \\
\text { yang diestimasi sebagai charge terhadap earnings tetapi } \\
\text { mengijinkan alternatif men-disclose biaya yang diestimas } \\
\text { dalam footnotes }\end{array}$ \\
\hline
\end{tabular}

Sumber: Disusun Penulis

\section{Gambar 1}

\section{Akuntansi Program Opsi Saham Eksekutif}




\section{Tinjauan Umum Pengelolaan Laba}

Teori akuntansi berbasis kontrak didasarkan pada premis bahwa manajer memilih kebijakan akuntansi tertentu baik secara efisien untuk memaksimumkan nilai perusahaan maupun secara oportunistik untuk kepentingan manajer dengan biaya beberapa pihak lain dalam kontrak (Gumanti, 2001). Dengan demikian terdapat dua cara yang saling melengkapi dalam memahami pengelolaan laba. Pertama, pengelolaan laba dapat dipandang sebagai perilaku oportunistik (opportunistic behavior) oleh manajer untuk memaksimumkan kepentingannya dalam menghadapi biaya kompensasi, kontrak utang, dan politis (Watts dan Zimmerman, 1990). Kedua, pengelolaan laba juga dapat dipandang dari perspektif kontrak efisien, yaitu pengelolaan laba memberi manajer beberapa fleksibilitas untuk melindungi dirinya sendiri dan perusahaan dalam menghadapi realisasi keadaan yang tidak diantisipasi untuk kepentingan seluruh pihak yang terlibat dalam kontrak (Christie dan Zimmerman, 1994).

Munculnya perilaku pengelolaan laba didorong oleh perubahan penguasaan perusahaan. Perusahaan terdiri atas manajemen (agen) yang ditunjuk atau diberi delegasi oleh pemegang saham (prinsipal) untuk membuat keputusan, keduanya berusaha memaksimumkan utilitasnya tetapi manajemen memiliki kesempatan yang lebih banyak untuk memaksimumkan utilitasnya. Manajer kemungkinan terlibat dalam beragam polapola pengelolaan laba di antaranya: (1) kepalang basah (taking a bath) merupakan tindakan menggeser biaya akrual diskresioner perioda mendatang ke perioda kini dan atau menggeser pendapatan akrual diskresioner perioda kini ke perioda mandatang, (2) meminimumkan laba ketika laba sebelum keputusan akrual lebih kecil daripada batas bawah (bogey) atau melebihi batas atas (cap), (3) memaksimumkan laba ketika laba sebelum keputusan akrual melebihi batas bawah tetapi tidak melebihi batas atas, dan (4) perataan laba (income smoothing) (Scott, 2009).

Pengelolaan laba merupakan area yang kontroversial dan penting dalam akuntansi keuangan. Beberapa pihak yang berpendapat bahwa pengelolaan laba merupakan perilaku yang tidak dapat diterima, mempunyai alasan bahwa pengelolaan laba berarti suatu pengurangan keandalan informasi laporan keuangan (Assih, 2004). Investor mungkin tidak menerima informasi yang cukup akurat mengenai laba untuk mengevaluasi return dan risiko portofolionya (Ashari et al., 1994). Bukti empiris menunjukkan bahwa luasnya pilihan praktik akuntansi dapat digunakan oleh manajer untuk mengelola laba sehingga angka laba tidak secara akurat mencerminkan hasil aktivitas ekonomi di masa lalu. Selanjutnya, investor tidak akan mampu membandingkan secara baik alternatif kesempatan investasinya (Simpson, 1969). Selanjutnya, beberapa pihak lain melihat dari sudut pandang kontrak yang efisien, mempunyai keinginan memberi beberapa kemampuan kepada manajer untuk melakukan pengelolaan laba dalam menghadapi berbagai kontrak yang tidak lengkap dan kaku. 


\section{Studi Penelitian Tentang Pengaruh Pengelolaan Laba dan Program Opsi Saham Eksekutif}

Tabel 2 menyajikan beberapa studi tentang pengelolaan laba atas penerapan program opsi saham eksekutif.

\section{Tabel 2}

Studi tentang Pengelolaan Laba dan Program Opsi Saham Eksekutif

\begin{tabular}{|c|c|c|c|c|}
\hline Peneliti & $\begin{array}{c}\text { Perioda dan } \\
\text { Jumlah Sampel }\end{array}$ & $\begin{array}{c}\text { Variabel } \\
\text { Opsi Sahan }\end{array}$ & $\begin{array}{c}\text { Variabel } \\
\text { Pengelolaan Laba }\end{array}$ & Hasil \\
\hline $\begin{array}{l}\text { Yermack } \\
(1997)\end{array}$ & $\begin{array}{c}1992-1994 \\
\text { (620 hibah opsi) }\end{array}$ & $\begin{array}{l}\text { Penyaatan hibah } \\
\text { opsi saham }\end{array}$ & $\begin{array}{l}\text { Penyaatan } \\
\text { pengumuman laba } \\
\text { untuk } \\
\text { mengidentifikasi } \\
\text { gerakan harga } \\
\text { saham }\end{array}$ & $\begin{array}{l}\text { Penentuan timing } \\
\text { hibah bersamaan } \\
\text { dengan gerakan } \\
\text { harga saham. }\end{array}$ \\
\hline $\begin{array}{c}\text { Gao \& } \\
\text { Shrieves } \\
(2002)\end{array}$ & $1992-2000$ & $\begin{array}{l}\text { Jumlah rupiah } \\
\text { gaji, bonus, opsi } \\
\text { saham, dan } \\
\text { restricted stock } \\
\text { serta intensitas } \\
\text { masing-masing } \\
\text { kompensasi }\end{array}$ & $\begin{array}{l}\text { Nilai absolut } \\
\text { akrual diskresioner }\end{array}$ & $\begin{array}{l}\text { Jumlah opsi saham } \\
\text { dan bonus serta } \\
\text { intensitas opsi } \\
\text { berhubungan positif } \\
\text { dengan intensitas } \\
\text { pengelolaan laba. }\end{array}$ \\
\hline $\begin{array}{c}\text { Balsam } \\
\text { et al. } \\
(2003)\end{array}$ & $1995-2001$ & $\begin{array}{l}\text { Opsi yang } \\
\text { dihibahkan ke } \\
\text { insider selama } \\
\text { jendela kejadian } \\
\text { di deflasi dengan } \\
\text { kepemilikan }\end{array}$ & $\begin{array}{l}\text { Akrual } \\
\text { diskresioner } \\
\text { kuartalan sebagai } \\
\text { prosentase dari } \\
\text { aset total yang di } \\
\text { lag menggunakan } \\
\text { Model Jones cross } \\
\text { sectional }\end{array}$ & $\begin{array}{l}\text { Terdapat pengaruh } \\
\text { negatif antara } \\
\text { akrual diskresioner } \\
\text { dan hibah opsi } \\
\text { saham berikutnya }\end{array}$ \\
\hline $\begin{array}{l}\text { Johnston- } \\
\text { Wilson } \\
(2003)\end{array}$ & $\begin{array}{c}\text { 2000-2002 } \\
\text { (45 perusahaan } \\
\text { yang mengakui } \\
\text { jumlah rupiah } \\
\text { opsi saham dan } \\
45 \text { perusahaan } \\
\text { yang tidak } \\
\text { mengakui jumlah } \\
\text { rupiah opsi } \\
\text { saham) }\end{array}$ & $\begin{array}{l}\text { Jumlah rupiah } \\
\text { opsi saham yang } \\
\text { dihibah dideflasi } \\
\text { dengan aset } \\
\text { tahun kemarin }\end{array}$ & $\begin{array}{l}\text { Faktor-faktor } \\
\text { model } \\
\text { penghargaan opsi } \\
\text { di antaranya } \\
\text { volatilitas harga } \\
\text { kejutan, suku } \\
\text { bunga bebas risiko } \\
\text { kejutan, dan } \\
\text { dividend yield } \\
\text { kejutan }\end{array}$ & $\begin{array}{l}\text { Perusahaan yang } \\
\text { mengakui jumlah } \\
\text { rupiah opsi saham } \\
\text { mengelola faktor } \\
\text { volatilitas harga } \\
\text { yang menurun } \\
\text { (relatif terhadap } \\
\text { perusahaan yang } \\
\text { tidak mengakui } \\
\text { jumlah rupiah opsi } \\
\text { saham) untuk } \\
\text { mengurangi jumlah } \\
\text { rupiah opsi saham } \\
\text { yang dilaporkan. }\end{array}$ \\
\hline
\end{tabular}




\section{Hipotesis Perilaku Pengelolaan Laba Menjelang Tanggal Penerapan Hibah Opsi Saham Eksekutif}

Penelitian sebelumnya mengidentifikasi 3 (tiga) tipe pengelolaan skedul yang dimaksudkan untuk menurunkan harga saham pada tanggal hibah. Pertama, eksekutif perusahaan yang menghibahkan opsi berdasarkan skedul tetap (fixed schedule), yang di dalamnya opsi dihibahkan pada saat yang sama setiap tahun, dapat mengelola penyaatan pengungkapan berita perusahaan di sekitar hibah opsi yang terprediksi dengan mempercepat berita buruk (bad news) sebelum tanggal hibah atau menunda berita baik (good news) sampai sesudah tanggal hibah (Aboody dan Kasznik, 2000).

Kedua, eksekutif perusahaan yang menghibahkan opsi tanpa skedul tetap, yang di dalamnya opsi dihibahkan pada saat yang berbeda dari tahun ke tahun (unscheduled awards), dapat mempengaruhi penyaatan hibah opsi yang menyebabkan opsi dihibahkan segera sesudah mengantisipasi pengumuman berita buruk atau segera sebelum mengantisipasi berita baik (Yermack, 1997; Chauvin dan Shenoy, 2000). Tipe ketiga pengelolaan penyaatan adalah memilih tanggal di masa lalu untuk dijadikan sebagai tanggal hibah yang harga sahamnya rendah (Lie, 2004). Dengan kata lain, tanggal hibah opsi dimundurkan (backdated) untuk disesuaikan dengan harga saham historis yang rendah sehingga eksekutif menerima opsi saham mereka dengan harga pengambilan yang relatif rendah pada tanggal hibah.

Informasi kebijakan hibah opsi saham penting bagi eksekutif yang menerima opsi saham karena hampir seluruh opsi saham eksekutif dihibahkan dengan harga pengambilan sama dengan harga saham pada tanggal hibah. Jika manajer mampu mempengaruhi struktur kontrak kompensasi, penelitian mengharap manajer akan menerima hibah opsi saham segera sebelum berita baik yang mendorong harga saham meningkat. Dengan kata lain, eksekutif dapat meningkatkan nilai opsi mereka dengan menerima opsi pada tanggal ketika harga saham perusahaan relatif rendah. Studi sebelumnya menemukan bahwa abnormal return saham negatif sebelum penawaran hibah opsi saham dan positif sesudah penawaran hibah opsi saham (Yermack, 1997; Aboody dan Kasznik, 2000; Chauvin dan Shenoy, 2000).

Pola return saham di sekitar penawaran opsi saham konsisten dengan perilaku oportunistik eksekutif yang bertujuan untuk meningkatkan nilai opsi mereka. Praktik ini mendapat perhatian akhir-akhir ini dari Securities and Exchange Commission (SEC) yang menguji apakah perusahaan menghibahkan opsi saham pada eksekutif sebelum mempublikasi berita baik atau mendukung (Knoll, 2009).

Oleh karena itu, hipotesis operasional dalam bentuk hipotesis alternatif dikembangkan sebagai berikut:

$\mathbf{H}_{1}$ : Menjelang tanggal hibah opsi saham eksekutif, proporsi opsi saham mempengaruhi perilaku manajemen dengan pola income decreasing 


\section{Hipotesis Perilaku Pengelolaan Laba Menjelang Akhir Penerapan Hibah Opsi Saham Eksekutif}

Opsi saham secara khas (typically) dihibahkan dengan harga pengambilan sama dengan harga saham pada tanggal hibah, hal tersebut menyebabkan manajemen secara oportunistik mengelola pengungkapan informasi untuk meningkatkan nilai hibah mereka. Strategi pengungkapan menjamin adanya penurunan harga saham perusahaan berkaitan dengan informasi buruk yang terjadi sebelumnya, sedangkan harga saham meningkat berkaitan dengan informasi baik yang terjadi sesudah hibah.

Untung (gain) dari opsi saham tergantung pada perbedaan antara harga pengambilan yang ditentukan pada tanggal hibah dengan harga pasar pada tanggal pengambilan. Untung tersebut semakin besar apabila magnituda opsi yang diterima relatif banyak. Untuk memaksimumkan untung yang akan diperoleh, manajemen memiliki insentif untuk menurunkan harga pasar saham untuk sementara waktu sebelum tanggal hibah dalam rangka mengurangi harga pengambilan opsi mereka (Chauvin dan Shenoy, 2000; Balsam et al., 2003) dan meningkatkan harga pasar mendatang pada tanggal pengambilan (Yermack, 1997). Dengan demikian, perilaku manajemen setelah tanggal hibah menunjukkan pola laba menaik (income increasing). Untung yang diperoleh bersifat realized menjelang vesting period tersebut berakhir, karena eksekutif dapat merealisasi selisih antara harga pengambilan dengan harga jual saham tersebut.

Oleh karena itu, hipotesis operasional dalam bentuk hipotesis alternatif dikembangkan sebagai berikut:

$\mathbf{H}_{2 \mathbf{a}}$ : $\quad$ Sebelum tanggal hibah opsi, pengaruh proporsi opsi saham pada pengelolaan laba menurun akan makin kuat pada tahap awal penerapan program opsi saham eksekutif

$\mathbf{H}_{2 \mathbf{b}}$ : Sebelum tanggal hibah opsi, pengaruh proporsi opsi saham pada pengelolaan laba menaik akan makin kuat pada tahap akhir penerapan program opsi saham eksekutif.

\section{METODE PENELITIAN}

\section{Sampel Penelitian}

Populasi penelitian ini mencakup perusahaan yang telah mempublik di Bursa Efek Indonesia (BEI). Perusahaan yang di pilih sebagai sampel dalam penelitian ini adalah perusahaan yang terdaftar di Bursa Efek Indonesia (BEI) yang telah menerapkan Program Opsi Saham Eksekutif dan dibatasi pada perusahaan yang mempublikasi laporan keuangan per 31 Desember untuk tahun buku 2007 sampai 2009. Standar mengenai kompensasi berbasis saham (opsi saham eksekutif) berlaku efektif pada tahun 1998, dan sebagian perusahaan baru menerapkan program opsi saham eksekutif mulai tahun 1999. 
Pemilihan sampel ditentukan secara bersasaran (purposive sampling) dengan tujuan untuk mendapatkan sampel yang representatif sesuai dengan kriteria yang ditentukan. Kriteria yang digunakan untuk memilih sampel adalah sebagai berikut ini.

1. Perusahaan yang sudah mempublik sebelum 31 Desember 2007 karena yang akan diamati dalam penelitian ini adalah penawaran opsi saham mulai tahun 2007 sampai dengan tahun 2009.

2. Emiten yang sudah menyertakan laporan keuangan per 31 Desember 2007, 2008, dan 2009. Pemilihan perioda tersebut didasarkan pada alasan bahwa laporan per 31 Desember merupakan laporan yang telah diaudit, sehingga laporan keuangan tersebut dapat lebih dipercaya. Selain itu, dalam perioda tersebut sebagian perusahaan telah menawarkan program opsi saham.

3. Emiten menawarkan program opsi saham eksekutif pada tahun 2007, 2008, dan 2009.

4. Emiten yang saham biasanya aktif diperdagangkan di BEJ, karena emiten yang sahamnya tidak aktif diperdagangkan akan mengganggu proses analisis, sehingga harus dikeluarkan dari sampel.

Sampel akhir penelitian ini menjadi sebanyak 21 sampel perusahaan. Jumlah observasi penelitian sebanyak 63 observasi.

\section{Data Penelitian}

Data yang diperlukan dalam penelitian ini merupakan jenis data sekunder yang terdiri atas:

a. Pelaporan keuangan untuk tahun buku yang berakhir tanggal 31 Desember 2007, 31

Desember 2008, dan 31 Desember 2009. Alasan penggunaan perioda tahun buku 2007, 2008, dan 2009 adalah bahwa dalam perioda tersebut sebagian perusahaan telah menawarkan program opsi saham eksekutif dalam tahun yang sama. Data program opsi saham tersebut diperoleh dari catatan atas laporan keuangan di perpustakaan BEI, database program magister sains dan doktor fakultas ekonomi UGM Jogjakarta, dan dari informasi melalui internet dengan corporate secretary masing-masing perusahaan sampel penelitian ini.

b. Data tanggal penawaran opsi saham per 31 Desember 2007-2009. Data ini digunakan untuk menentukan perioda penerapan kompensasi opsi saham masing-masing emiten baik pada saat menjelang tanggal hibah maupun menjelang berakhirnya vesting period pelaksanaan opsi saham eksekutif.

\section{Variabel dan Definisi Operasional Variabel}

Variabel dependen hipotesis 1 dan 2 adalah akrual diskresioner yang diestimasi menggunakan model Jones modifikasian (modified Jone's model) (Dechow et al., 1995) untuk mengukur tingkat pengelolaan laba. Variabel independen adalah proporsi opsi saham $\left(\mathrm{HB}_{\mathrm{it}}\right)$ yang ditawarkan perusahaan kepada eksekutif. Dengan kata lain, $\mathrm{HB}_{\mathrm{it}}$ adalah proporsi opsi yang dihibahkan kepada eksekutif selama bingkai kejadian (event window) untuk mengestimasi besarnya kesempatan untuk melakukan pengelolaan laba 
perusahaan dengan adanya penghibahan opsi saham perusahaan i pada perioda t. Variabel pemoderasi adalah tahapan-tahapan pelaksanaan opsi saham.

\section{Pengukuran Proporsi Opsi Saham Eksekutif}

Proporsi opsi saham eksekutif digunakan sebagai variabel independen yang nilainya ditentukan untuk menguji adanya pengelolaan laba. Sebagaimana Balsam et al. (2003), proporsi opsi saham eksekutif adalah jumlah lembar opsi saham yang dihibahkan pada eksekutif selama jendela kejadian (event window) dideflasi dengan kepemilikan manajerial. Harapan penelitian ini adalah koefisien variabel hibah negatif untuk perioda sebelum penawaran opsi saham. Dengan demikian, sebagaimana telah dikemukakan di atas, eksekutif menginginkan menurunkan harga saham sebagai antisipasi penawaran hibah opsi saham.

\section{Pengukuran Pengelolaan Laba}

Dalam hipotesis 1 dan 2 penelitian ini, perilaku oportunistik manajer difokuskan pada pengelolaan akrual. Berdasarkan pada model Healy (1985), Jones (1991) memperkenalkan model untuk memisahkan akrual diskresioner (tingkat akrual yang abnormal) dari akrual nondiskresioner (tingkat akrual yang wajar/normal). Pengelolaan laba diukur menggunakan proksi akrual diskresioner. Jones menggunakan regresi untuk memisahkan akrual diskresioner dengan akrual nondiskresioner. Modifikasi model estimasi akrual yang akan digunakan dalam penelitian ini adalah:

$$
\mathrm{TA}_{\mathrm{it}} / \mathrm{A}_{\mathrm{it}-1}=\alpha_{1}\left(1 / \mathrm{A}_{\mathrm{it}-1}\right)+\beta_{1}\left(\Delta \mathrm{REV} \mathrm{V}_{\mathrm{it}} / \mathrm{A}_{\mathrm{it}-1}\right)+\beta_{2}\left(\mathrm{PPE}_{\mathrm{it}} / \mathrm{A}_{\mathrm{it}-1}\right)+\varepsilon_{\mathrm{it}}
$$

dalam persamaan di atas $\mathrm{TA}_{\text {it }}$ adalah akrual total perusahaan i pada perioda $\mathrm{t}, \mathrm{A}_{\mathrm{it}-1}$ adalah aktiva total perusahaan i pada perioda $\mathrm{t}-1, \Delta \mathrm{REV}_{\text {it }}$ adalah pendapatan perusahaan i pada perioda $t$ dikurangi pendapatan perusahaan i pada perioda $t-1, P E_{i t}$ adalah aktiva tetap perusahaan $\mathrm{i}$ pada perioda $\mathrm{t}, \varepsilon_{\mathrm{it}}$, adalah residual error perusahaan $\mathrm{i}$ pada perioda $\mathrm{t}$. Perubahan pendapatan $\beta_{1}\left(\Delta \mathrm{REV}_{\mathrm{it}} / \mathrm{A}_{\mathrm{it}-1}\right)$ dimasukkan ke dalam model estimasi tersebut untuk mengendalikan perubahan dalam akrual nondiskresioner yang disebabkan oleh perubahan kondisi.

Pendapatan digunakan sebagai kontrol terhadap lingkungan perusahaan karena pendapatan merupakan ukuran obyektif dari operasi perusahaan sebelum manipulasi manajer (Jones, 1991). Sedangkan $\beta_{2}\left(\mathrm{PPE}_{\mathrm{it}} / \mathrm{A}_{\mathrm{it}-1}\right)$ merupakan bagian dari akrual total yang berhubungan dengan biaya depresiasi yang nondiskresioner.

Dechow et al., (1995) menguji berbagai alternatif model akrual dan penelitian menunjukkan bahwa model modifikasi Jones merupakan model yang paling baik untuk menguji pengelolaan laba. Model modifikasi Jones adalah sebagai berikut:

$$
\left.\mathrm{TA}_{\mathrm{it}} / \mathrm{A}_{\mathrm{it}-1}=\beta_{1}\left(1 / \mathrm{A}_{\mathrm{it}-1}\right)+\beta_{2}\left(\Delta \mathrm{REV}_{\mathrm{it}}-\Delta \mathrm{REC}_{\mathrm{it}}\right) / \mathrm{A}_{\mathrm{it}-1}\right)+\beta_{3}\left(\mathrm{PPE}_{\mathrm{it}} / \mathrm{A}_{\mathrm{it}-1}\right)+\varepsilon_{\mathrm{it}}
$$


Dalam persamaan di atas $\triangle \mathrm{REC}_{\text {it }}$ adalah piutang perusahaan i pada perioda $\mathrm{t}$ dikurangi piutang perusahaan i pada perioda t-1. TA $\mathrm{A}_{\mathrm{it}}, \mathrm{A}_{\mathrm{it}-1}, \Delta \mathrm{REV}_{\mathrm{it}}, \mathrm{PPE}_{\mathrm{it}}$, dan $\varepsilon_{\mathrm{it}}$ didefinisi dalam persamaan (1). Ordinary least squares digunakan untuk mendapatkan nilai $\mathrm{a}_{1}, \mathrm{~b}_{1}$, dan $\mathrm{b}_{2}$ sebagai estimator parameter $\beta_{1}, \beta_{2}$, dan $\beta_{3}$. Keterbatasan data yang tersedia (laporan keuangan tahun buku 1999-2002) tidak memungkinkan peneliti untuk melakukan regresi setiap perusahaan i menggunakan model Jones. Oleh karena itu, sebagaimana pernah dilakukan oleh Defond dan Jiambalvo (1994), Cahan (1992), Naim dan Hartono (1996) serta Hall dan Stammerjohan (1997), peneliti melakukan regresi untuk seluruh observasi.

Variabel residual error, $\varepsilon_{\text {it }}$, dari persamaan (2) merupakan tingkat akrual diskresioner. Dengan demikian, proksi pertama akrual diskresioner yang akan digunakan dalam penelitian ini adalah:

$$
\mathrm{DA}_{\mathrm{it}}=\mathrm{TA}_{\mathrm{it}-1} / \mathrm{A}_{\mathrm{it}-1}-\left[\mathrm{a}_{1}\left(1 / \mathrm{A}_{\mathrm{it}-1}\right)+\mathrm{b}_{2}\left(\Delta \mathrm{REV}_{\mathrm{it}}-\Delta \mathrm{REC}_{\mathrm{it}} / \mathrm{A}_{\mathrm{it}-1}\right)+\mathrm{b}_{3}\left(\mathrm{PPE}_{\mathrm{it}} / \mathrm{A}_{\mathrm{it}-1}\right)\right]
$$

dalam persamaan di atas $D_{i t}$ adalah akrual diskresioner perusahaan $i$ pada perioda $t$. $\mathrm{TA}_{\mathrm{it}}, \mathrm{A}_{\mathrm{it}-1}, \Delta \mathrm{REV}_{\mathrm{it}}, \triangle \mathrm{REC}_{\mathrm{it}}$, dan $\mathrm{PPE}_{\mathrm{it}}$ didefinisi dalam persamaan (1) dan (2). Proksi akrual nondiskresioner yang kedua adalah akrual rata-rata seluruh observasi. Diasumsi bahwa tingkat akrual normal pada suatu tahun dapat dijelaskan dengan nilai aktiva.

\section{Teknik Analisis}

Penelitian ini menggunakan alat analisis utama yaitu regresi linear berganda karena pada penelitian ini dipelajari/dianalisis ketergantungan suatu variabel (yaitu variabel dependen) dengan cara mengestimasi atau memprediksi nilai rata-rata variabel dependen dalam kaitannya dengan nilai variabel independen yang telah diketahui. Untuk menguji pengaruh proporsi hibah opsi saham terhadap akrual diskresioner, spesifikasi model penelitian ini adalah sebagai berikut:

\section{Model Penelitian:}

$$
\begin{aligned}
& \mathrm{AD}_{\text {it }}=\beta_{0}+\beta_{1} \mathrm{HB}_{\text {it }}+\varepsilon_{\text {it }} \\
& \mathrm{AD}_{\text {it }}=\beta_{0}+\beta_{1} \mathrm{HB}_{\text {it }}+\beta_{2} \mathrm{~T} 2_{\text {it }}+\beta_{3} \mathrm{~T} 3_{\text {it }}+\beta_{4} \mathrm{~T} 2_{\mathrm{it}} * \mathrm{HB}_{\mathrm{it}}+\beta_{5} \mathrm{~T}_{\text {it }} * \mathrm{HB}_{\mathrm{it}}+\varepsilon_{\text {it }}
\end{aligned}
$$

dalam persamaan di atas $\mathrm{AD}_{\text {it }}$ adalah akrual diskresioner, $\mathrm{HB}_{\text {it }}$ adalah proporsi opsi saham, T2 it adalah dummy (kategoris) tahap ke-2, dan T3 it adalah dummy (kategoris) tahap ke-3. Secara statistis, apabila $\beta_{1}$ dalam persamaan di atas signifikan menunjukkan bahwa terdapat perilaku manajemen mengelola laba menurun sebelum tanggal hibah opsi.

\section{ANALISIS DAN PEMBAHASAN}

\section{Statistik Deskriptif}

Tabel 3 manyajikan ringkasan statistis deskriptif atas variabel-variabel penelitian untuk sampel perusahaan dan tahapan-tahapan penawaran opsi saham secara keseluruhan untuk menguji perilaku manajemen atas penawaran opsi saham eksekutif. 
Tabel 3

Statistis Deskriptif Variabel Penelitian

\begin{tabular}{lccccc}
\hline \hline Variabel & N & Rata-Rata & Deviasi Standar & Minimum & Maksimum \\
\hline AD & 63 & 0.062 & 0.101 & -0.250 & 0.380 \\
HB & 63 & 0.021 & 0.021 & 0.000 & 0.090 \\
T2 & 63 & 0.413 & 0.496 & 0.000 & 1.000 \\
T3 & 63 & 0.191 & 0.396 & 0.000 & 1.000 \\
T2*HB & 63 & 0.005 & 0.009 & 0.000 & 0.030 \\
T3*HB & 63 & 0.002 & 0.006 & 0.000 & 0.020 \\
\hline
\end{tabular}

Keterangan:

$\mathrm{AD}=$ Akrual Diskresioner (\%), HB = Hibah Opsi Saham (\%), T2 = Dummy (Kategoris) Tahap 2, T3 = Dummy (Kategoris) Tahap 3

Data rata-rata dan deviasi standar digunakan untuk menentukan fluktuasi masing-masing variabel yang diuji, sedang data minimum dan maximum menunjukkan kisar (range) data yang normal untuk menghindari hasil penelitian yang bias. Nilai rata-rata akrual diskresioner seelah penawaran opsi saham menunjukkan nilai positif sebesar 0,062. Hasil penelitian menunjukkan bahwa perusahaan-perusahaan secara umum melakukan pengelolaan laba dan manajemen lebih memilih kebijakan akrual yang menaikkan laba sesudah tanggal hibah opsi saham. Deviasi standar seluruh variabel nilainya relatif kecil, hal tersebut menunjukkan bahwa perilaku pengelolaan laba perusahaan dalam sampel berkaitan dengan program opsi saham eksekutif tidak terlalu bervariasi. Nilai deviasi standar yang tidak terlalu besar tersebut juga menunjukkan bahwa tingkat penyimpangan masing-masing variabel tidak signifikan.

\section{Hipotesis 1}

Pengujian pengelolaan laba berkaitan dengan program opsi saham eksekutif menjelang tanggal hibah dinilai dengan menggunakan data laporan keuangan mulai tahun 2007 sampai dengan tahun 2009. Hasil analisis dalam tabel 4 menunjukkan bahwa koefisien HB $\left(\beta_{1}\right)$ sebesar $-2,098$ dengan p-value sebesar 0,000 , dengan demikian secara statistis signifikan pada tingkat $1 \%$ sesuai dengan prediksi. Hal ini menunjukkan bahwa semakin banyak opsi saham yang ditawarkan pada eksekutif maka manajer semakin termotivasi untuk melakukan pengelolaan laba menurun sebelum penawaran opsi saham. Hasil konsisten dengan penelitian-penelitian sebelumnya yaitu adanya perilaku manajer yang mengharapkan penurunan harga saham menjelang tanggal penawaran opsi saham dengan tujuan memperoleh harga pengambilan yang rendah, sehingga manajer membayar kompensasi opsi saham tersebut dengan harga yang relatif murah. Dengan demikian penelitian ini berhasil menolak $\mathrm{H}_{01}$. Penelitian ini konsisten dengan studi Chauvin \& Shenoy (2000), Baker et al., (2002), dan Balsam et al., (2003). 


\section{Tabel 4}

Hasil Regresi Hipotesis 1

\begin{tabular}{lccl}
\hline \hline \multicolumn{1}{c}{ Variabel } & Koefisien & Nilai t-statistik & \multicolumn{1}{c}{ Nilai $\mathbf{p}$} \\
\hline Intercept & $-0,020$ & $-0,914$ & 0,364 \\
HB & $-2,098$ & $-4,086$ & $0,000 * * *$ \\
T2 & 0,073 & 2,233 & $0,029 * *$ \\
T3 & $-0,115$ & $-2,497$ & $0,015 * *$ \\
T2*HB & 1,600 & 0,915 & 0,364 \\
T3*HB & 9,252 & 3,131 & $0,003 * *$ \\
& & & \\
R2 (Adjusted) & $0,487(0,442)$ & & \\
F & $10,839 * * *$ & & \\
\hline
\end{tabular}

Keterangan:

HB = Hibah Opsi Saham, T2 = Dummy (Kategoris) Tahap 2, T3 = Dummy (Kategoris) Tahap 3

*** Secara statistis signifikan pada tingkat 0,01

** Secara statistis signifikan pada tingkat 0,05

* Secara statistis signifikan pada tingkat 0,10

Hasil penelitian menunjukkan bahwa nilai $\mathrm{F}$ kalkulasian sebesar 10,839 dengan nilai probabilitas 0,000 secara statistis signifikan pada tingkat $1 \%$. Besarnya $R^{2}$ adalah 0,487 yang berarti bahwa variasi tingkat akrual diskresioner (AD) dijelaskan oleh proporsi hibah opsi saham eksekutif (HB) sebesar 48,7\%. Sisanya sebesar 51,3\% dijelaskan oleh variabel-variabel lain yang tidak dimasukkan dalam Model. Perilaku oportunistik di sekitar penawaran hibah opsi saham mendukung Lie (2004) bahwa komite kompensasi yang menentukan jumlah dan penyaatan hibah opsi saham, tetapi terdapat beberapa alasan untuk menyarankan bahwa eksekutif mempengaruhi keputusan komite kompensasi. Pertama, Yermack (1997) menemukan bahwa eksekutif sering mengusulkan parameter hibah opsi saham, sedangkan komite kompensasi hanya mensahkan usulan tersebut. Kedua, eksekutif kemungkinan mempengaruhi keputusan komite melalui pertemanan yang dekat (close friendships) dengan anggota komite individual. Ketiga, eksekutif kemungkinan mempengaruhi saat pertemuan (meetings) komite kompensasi, yang secara reguler bertepatan dengan tanggal hibah (Bartov dan Mohanram, 2004).

\section{Hipotesis 2a dan 2b}

Pengujian pengelolaan laba berkaitan dengan program opsi saham eksekutif sesudah tanggal hibah dinilai dengan menggunakan data laporan keuangan mulai tahun 2007 sampai dengan tahun 2009. Hasil analisis dalam tabel 5 menunjukkan bahwa koefisien HB $\left(\beta_{1}\right)$ bernilai positif sebesar 7,499 dengan p-value sebesar 0,039 , dengan demikian secara statistis signifikan pada tingkat $5 \%$ sesuai dengan prediksi. Hal ini menunjukkan bahwa semakin banyak opsi saham yang ditawarkan pada eksekutif maka manajer semakin termotivasi melakukan pengelolaan laba menaik sesudah penawaran opsi saham. Dengan demikian penelitian ini berhasil menolak $\mathrm{H}_{02 a}$. Hasil menunjukkan bahwa pada 
tahap awal, terdapat kecendrungan perilaku eksekutif yang menginginkan income increasing. Penelitian ini konsisten dengan Yermack (1997) dan Gao \& Shrieves (2002).

Hasil analisis dalam tabel 5 juga menunjukkan bahwa koefisien $\mathrm{T} 3 * \mathrm{HB}\left(\beta_{5}\right)$ bernilai positif sebesar 0,109 dengan p-value sebesar 0,010, dengan demikian secara statistis signifikan pada tingkat 5\% sesuai dengan prediksi. Hal ini juga menunjukkan bahwa semakin banyak opsi saham yang ditawarkan maka eksekutif semakin termotivasi untuk melakukan pengelolaan laba menaik sesudah penawaran opsi saham. Hasil konsisten dengan penelitian sebelumnya yaitu adanya perilaku manajer yang mengharap kenaikan harga saham sesudah tanggal penawaran opsi saham dengan tujuan memperoleh untung yang tinggi atas selisih antara harga pengambilan pada tanggal hibah dengan harga saham pada tanggal pengambilan. Dengan demikian penelitian ini berhasil menolak $\mathrm{H}_{02 \mathrm{~b}}$.

Tabel 5

\section{Hasil Regresi Hipotesis 2}

\begin{tabular}{lccc}
\hline \hline \multicolumn{1}{c}{ Variabel } & Koefisien & Nilai t-statistik & Nilai p \\
\hline Intercept & 0,005 & 0,195 & 0,846 \\
HB & 7,499 & 2,111 & $0,039 * *$ \\
T2 & 1,514 & 2,364 & $0,022 * *$ \\
T3 & $-0,088$ & $-1,578$ & 0,120 \\
T2*HB & $-0,089$ & $-0,043$ & 0,966 \\
T3*HB & 0,109 & 2,666 & $0,010 * *$ \\
R2 (Adjusted) & & \\
F & $0,339(0,281)$ & \\
Keterangan: & $5,839 * * *$ & \\
HB = Hibah Opsi Saham, T2 = Dummy (Kategoris) Tahap 2, T3 = Dummy (Kategoris) Tahap 3 & \\
*** Secara statistis signifikan pada tingkat 0,01 & & \\
** Secara statistis signifikan pada tingkat 0,05 & & \\
* Secara statistis signifikan pada tingkat 0,10 &
\end{tabular}

Hasil penelitian menunjukkan bahwa nilai $\mathrm{F}$ kalkulasian sebesar 5,839 dengan nilai probabilitas sebesar 0,000 , dengan demikian secara statistis signifikan pada $1 \%$. Besarnya $\mathrm{R}^{2}$ adalah 0,339 artinya variasi tingkat akrual diskresioner dijelaskan oleh proporsi opsi saham 33,9\%. Sisanya 66,1\% dijelaskan variabel lain yang tidak ada dalam Model.

Penelitian ini menguji lebih lanjut apakah terdapat perbedaan secara statistis tahap-tahap penawaran opsi saham tersebut. Pengujian menggunakan dua analisis. Pertama, untuk membandingkan baik konstanta maupun koefisien antar regresi tahap 1, tahap 2, dan tahap 3, analisis menggunakan t-test yang dikembangkan Sarkar dalam Prawitt et al. (2009). Perbandingan dilakukan untuk regresi: (1) tahap 1 dan tahap 2, (2) tahap 2 dan tahap 3, serta (3) tahap 1 dan tahap 3. Kedua, untuk menguji perbedaan antar tahap 
penawaran opsi dilakukan dengan membandingkan $t$-test dengan t tabel. Uji $t$-test untuk membandingkan konstanta dan koefisien regresi baik tahap 1, tahap 2, dan tahap 3.

Uji $t$-test untuk membandingkan konstanta dan koefisien regresi tahap 1 dan tahap 2 mengikuti formula sebagai berikut:

$$
\begin{aligned}
& \hat{\alpha}_{\kappa}{ }^{(1)}-\hat{\alpha}_{\kappa_{k}}{ }^{(2)}
\end{aligned}
$$

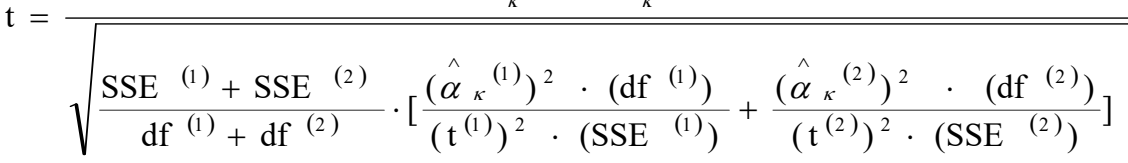

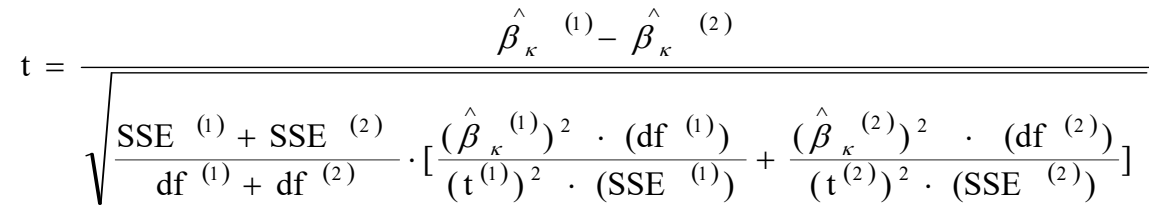

Uji t-test untuk membandingkan regresi tahap 1 dan tahap 3:

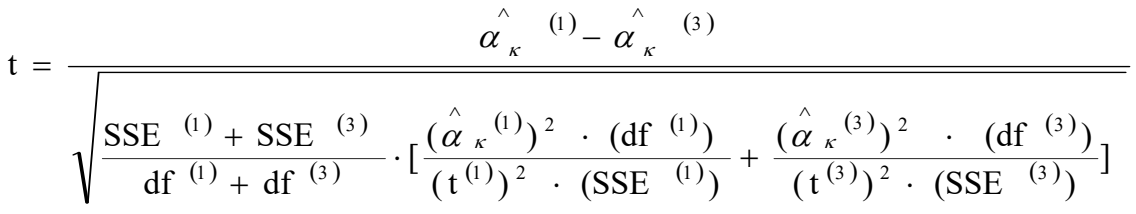

$$
\begin{aligned}
& \mathrm{t}=\frac{{\hat{\beta_{\kappa}}}^{(1)}-{\hat{\beta_{\kappa}}}^{(3)}}{\left.\sqrt{\frac{\operatorname{SSE}^{(1)}+\operatorname{SSE}^{(3)}}{\mathrm{df}^{(1)}+\mathrm{df}^{(3)} \cdot\left[\hat{\beta}_{\kappa}^{(1)}\right)^{2} \cdot\left(\mathrm{df}^{(1)}\right)}\left(\mathrm{t}^{(1)}\right)^{2} \cdot\left(\operatorname{SSE}{ }^{(1)}\right)}+\frac{\left(\hat{\beta}_{\kappa}^{(3)}\right)^{2} \cdot\left(\mathrm{df}^{(3)}\right)}{\left(\mathrm{t}^{(3)}\right)^{2} \cdot\left(\mathrm{SSE}^{(3)}\right)}\right]}
\end{aligned}
$$

Uji t-test untuk membandingkan regresi tahap 2 dan tahap 3:

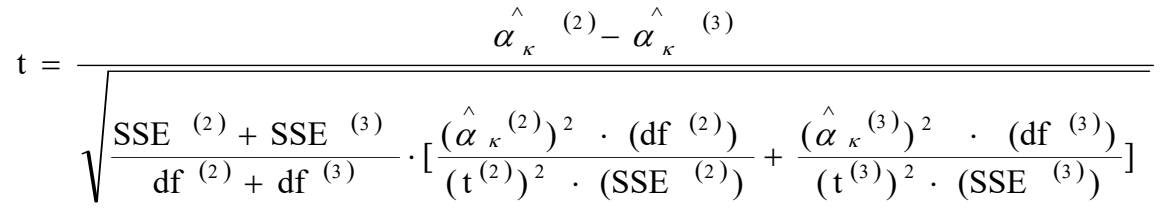

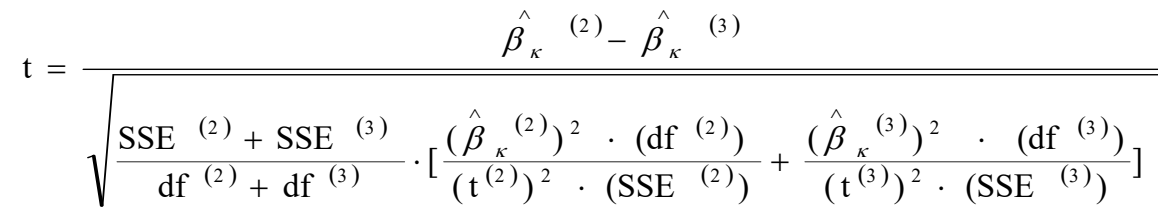


dalam persamaan di atas $\beta_{\mathrm{k}}^{(1)}$ adalah beta tahap $1, \beta_{\mathrm{k}}^{(2)}$ adalah beta tahap $2, \beta_{\mathrm{k}}{ }^{(3)}$ adalah beta tahap 3, $\mathrm{SSE}^{(1)}$ adalah jumlah galat kuadratan (sum of the squared error) tahap 1, $\mathrm{SSE}^{(2)}$ adalah jumlah galat kuadratan tahap 2, $\mathrm{SSE}^{(3)}$ adalah jumlah galat kuadratan tahap 3 , $\mathrm{df}^{(1)}$ adalah derajat kebebasan (degrees of freedom) tahap 1, $\mathrm{df}^{(2)}$ adalah derajat kebebasan tahap 2, $\mathrm{df}^{(3)}$ adalah derajat kebebasan tahap 3, $\mathrm{t}^{(1)}$ adalah nilai t tahap $1, \mathrm{t}^{(2)}$ adalah nilai $\mathrm{t}$ tahap 2 , dan $\mathrm{t}^{(3)}$ adalah nilai t tahap 3 .

Tabel 6 menyajikan nilai konstanta dan koefisien untuk masing-masing tahap penawaran opsi pengujian hipotesis $2 \mathrm{a}$.

Tabel 6

Nilai t-test Perbandingan Konstanta dan Koefisien Tahapan Penawaran Opsi (Hipotesis 2a)

\begin{tabular}{lccc}
\hline \hline \multicolumn{1}{c}{ Perbandingan } & t-test & t-tabel & Hasil \\
\hline Tahap 1 dan 2 & & & \\
Konstanta & 0,134 & $\left.2,023^{* *}\right)$ & Tidak Berbeda \\
Koefisien & $-0,389$ & $\left.1,691^{*}\right)$ & \\
Tahap 1 dan 3 & & & \\
Konstanta & 0,388 & $\left.2,036^{* *}\right)$ & Tidak Berbeda \\
Koefisien & 0,325 & $1,699^{*}$ & \\
Tahap 2 dan 3 & & & \\
Konstanta & 0,534 & $\left.2,064^{* *}\right)$ & Tidak Berbeda \\
Koefisien & 0,708 & $1,725^{*}$ & \\
& & & \\
\hline
\end{tabular}

Keterangan:

$\mathrm{n}$ Tahap $1=21$, $\mathrm{n}$ Tahap $2=21$, $\mathrm{n}$ Tahap $3=21$, df Tahap 1 dan Tahap $2=\mathrm{n} 1+\mathrm{n} 2-2 \mathrm{k}$, df Tahap 1 dan Tahap $3=\mathrm{n} 1+\mathrm{n} 3-2 \mathrm{k}$, df Tahap 2 dan Tahap $3=\mathrm{n} 2+\mathrm{n} 3-2 \mathrm{k}$.

** t-tabel didasarkan pada tingkat 0,05

* t-tabel didasarkan pada tingkat 0,10

Hasil menunjukkan bahwa untuk setiap perbandingan tahap-tahap dalam penawaran opsi saham, nilai t-test lebih kecil dibandingkan t-tabel. Dengan demikian tidak terdapat perbedaan pengaruh penyaatan terhadap perilaku pengelolaan laba manajemen berkaitan dengan program opsi saham eksekutif untuk setiap tahapan penawaran opsi saham. Perbedaan konstanta dan koefisien pada tahap 2 untuk seluruh observasi menunjukkan adanya pengaruh penyampelan yang dilakukan dalam penelitian ini berkaitan dengan target populasi yang ditetapkan.

Tabel 7 menyajikan nilai konstanta dan koefisien untuk masing-masing tahap penawaran opsi pengujian hipotesis $2 b$. 


\section{Tabel 7}

\section{Nilai t-test Perbandingan Konstanta dan Koefisien}

Tahapan Penawaran Opsi (Hipotesis 2b)

\begin{tabular}{lccc}
\hline \hline \multicolumn{1}{c}{ Perbandingan } & t-test & t-tabel & Hasil \\
\hline Tahap 1 dan 2 & & & \\
Konstanta & $-2,574$ & $\left.2,052^{* *}\right)$ & $\begin{array}{c}\text { Konstanta } \\
\text { Berbeda }\end{array}$ \\
Koefisien & $-0,459$ & $1,703^{*}$ & Tidak Berbeda \\
Tahap 1 dan 3 & & & \\
Konstanta & 0,371 & $\left.2,201^{* *}\right)$ & \\
Koefisien & 1,751 & $1,796^{*}$ & Koefisien \\
Tahap 2 dan 3 & 1,008 & $2,179^{* *}$ & Berbeda \\
Konstanta & 1,997 & $1,782^{*}$ & \\
Koefisien & & &
\end{tabular}

Keterangan:

$\mathrm{n}$ Tahap $1=21$, n Tahap $2=21$, $\mathrm{n}$ Tahap $3=21$, df Tahap 1 dan Tahap $2=\mathrm{n} 1+\mathrm{n} 2-2 \mathrm{k}$, df Tahap 1 dan Tahap $3=\mathrm{n} 1+\mathrm{n} 3-2 \mathrm{k}$, df Tahap 2 dan Tahap $3=\mathrm{n} 2+\mathrm{n} 3-2 \mathrm{k}$.

** t-tabel didasarkan pada tingkat 0,05

* t-tabel didasarkan pada tingkat 0,10

Hasil menunjukkan bahwa terdapat perbedaan konstanta antara tahap 1 dan tahap 2, yang tidak berbeda adalah konstanta tahap 1 dengan tahap 3 dan antara tahap 2 dengan tahap 3 . Sedangkan koefisien tahap 1 dan 2 besarnya sama, dengan demikian setiap perubahan hibah yang diberikan mempengaruhi besarnya akrual diskresioner yang besarnya sama. Akan tetapi dibandingkan tahap 3, lereng tahap 3 lebih tajam dibandingkan dengan lereng tahap 1 dan 2, sehingga adanya penambahan hibah opsi yang sama akan menyebabkan perubahan akrual diskresioner yang lebih tajam pada tahap 3 dibandingkan tahap 1 dan 2. Diindikasi hal tersebut terjadi karena pada perioda sesudah penawaran opsi, tahap 2 dan 3 penawaran opsi saham tujuannya sudah hampir searah, dengan kata lain pada perioda tersebut rata-rata manajer mengharapkan harga saham menaik.

\section{SIMPULAN, SARAN, DAN KETERBATASAN}

\section{Simpulan}

Pengujian pengelolaan laba berkaitan dengan program opsi saham eksekutif menjelang tanggal hibah dinilai dengan menggunakan data laporan keuangan mulai tahun 2007 sampai dengan tahun 2009. Hasil analisis pengujian $\mathrm{H}_{1}$ menunjukkan bahwa semakin banyak opsi saham yang ditawarkan pada eksekutif maka manajer semakin termotivasi untuk melakukan pengelolaan laba menurun sebelum penawaran opsi saham. Hasil konsisten dengan penelitian-penelitian sebelumnya yaitu adanya perilaku manajer yang mengharapkan penurunan harga saham menjelang tanggal penawaran opsi saham dengan 
tujuan memperoleh harga pengambilan yang rendah, sehingga manajer membayar kompensasi opsi saham tersebut dengan harga yang relatif murah. Dengan demikian penelitian ini berhasil menolak $\mathrm{H}_{01}$. Penelitian ini konsisten dengan studi Chauvin \& Shenoy (2000), Baker et al. (2002), dan Balsam et al. (2003). Hasil pengujian $\mathrm{H}_{2 \mathrm{a}}$ dan $\mathrm{H}_{2 b}$ menunjukkan bahwa semakin banyak opsi saham yang ditawarkan pada eksekutif maka manajer semakin termotivasi untuk melakukan pengelolaan laba menaik sesudah penawaran opsi saham. Dengan demikian penelitian ini berhasil menolak $\mathrm{H}_{02 \mathrm{a}}$ dan $\mathrm{H}_{02 \mathrm{~b}}$. Hasil menunjukkan bahwa pada tahap awal penerapan program opsi saham eksekutif, terdapat kecendrungan perilaku eksekutif yang menginginkan income increasing sampai dengan vesting period berakhir. Penelitian ini konsisten dengan studi Yermack (1997) dan Gao dan Shrieves (2002).

\section{Saran}

Penelitian selanjutnya perlu mempertimbangkan faktor-faktor yang lain yang kemungkinan mempengaruhi perilaku manajemen untuk melakukan manajemen laba. Di samping itu, pengujian dengan pengamatan yang lebih lama diharapkan untuk memperoleh sampel penelitian yang cukup banyak dan memberikan hasil yang lebih baik.

\section{Keterbatasan Penelitian}

Penelitian ini hanya mempertimbangkan variabel kompensasi jangka panjang berbasis saham dalam kaitannya dengan perilaku manajemen untuk mengelola laba karena dipengaruhi oleh kesulitan peneliti memperoleh data mengenai kompensasi jangka pendek dan kompensasi non fisik. Sampel penelitian terdiri atas beberapa jenis industri karena terbatasnya sampel penelitian perusahaan yang melakukan program opsi saham eksekutif dan belum dilakukan pengujian dampak industri pada hasil penelitian.

\section{DAFTAR PUSTAKA}

Aboody, D. dan R. Kasznik. 2000. CEO Stock Option Awards and The Timing of Corporate Voluntary Disclosures. Journal of Accounting and Economics 29: 73100.

Adli. 2001. Asosiasi Desain Kompensasi Insentif dan Motivasi Kerja Manajer dengan Misi Strategik sebagai Variabel Pemoderasi. Tesis.

Ashari, N., H.C. Koh, S.L. Tan, dan W.H. Wong. 1994. Factors Affecting Income Smoothing Among Listed Companies in Singapore. Accounting and Business Research, Vol. LI, No. 4: 707-723.

Assih, P. 2004. Pengaruh Set Kesempatan Investasi terhadap Hubungan antara FaktorFaktor Motivasional dan Tingkat Manajemen Laba. Disertasi. 
Baker, T., D. Collins, dan A. Reitenga. 2002. Stock Option Compensation and Earnings Management Incentives. Working Paper.

Ball, R. dan P. Brown. 1968. An Empirical Evaluation of Accounting Income Numbers. Journal of Accounting Research (Autumn): 159-178.

Balsam, S., H. Chen, dan S. Sankaraguruswamy. 2003. Earnings Management Prior to Stock Option Grants. Working Paper. Temple University dan Georgetown University.

Bartov, E. dan P. Mohanram. 2004. Private Information, Earnings Manipulations and Executive Stock-Option Exercises. Accounting Review 79 (4): 889-920.

Cahan, S.F. 1992. The Effect of Antitrust Investigations on Discretionary Accruals: A Refined Test of The Political-Cost Hypotheses. Accounting Review (January): 7795.

Chauvin, K.W. dan C. Shenoy. 2000. Stock Price Decreases Prior to Executive Stock Option Grants. Journal of Corporate Finance 7: 53-76.

Christie, A. dan J.L. Zimmerman. 1994. Efficient and Opportunistic Choice of Accounting Procedures: Corporate Control Contests. Accounting Review, Vol. 69, No. 4 (October): 539-566.

Dechow, P.M., R.G. Sloan, dan A.P. Sweeney. 1995. Detecting Earnings Management. Accounting Review (April): 193-225.

DeFond, M.L. dan J. Jiambalvo. 1994. Debt Covenant Violation and Manipulation of Accruals. Journal of Accounting and Economics, 17: 145-176.

Financial Accounting Standards Board. 1995. Accounting For Stock-Based Compensation. Statement of Financial Accounting Standard No. 123. Norwalk, Conn.: FASB (Oktober).

Gao, P. dan R.E. Shrieves. 2002. Earnings Management and Executive Compensation: A Case of Overdose of Option and Underdose of Salary. Working Paper.

Gaver, J.J., K.M. Gaver, dan J. Austin. 1995. Additional Evidence on Bonus Plans and Income Management. Journal of Accounting and Economics 3: 3-28.

Gumanti, T.A. 2001. Earnings Management dalam Penawaran Saham Perdana di Bursa Efek Jakarta. Jurnal Riset Akuntansi Indonesia 4/2: 165-183. 
Hall, S.C. dan W.W. Stammerjohan. 1997. Damage Awards and Earnings Management in the Oil Industry. Accounting Review (January): 47-65.

Healy, P.M. 1985. The Effect of Bonus Schemes on Accounting Decisions. Journal of ccounting and Economics 7: 85-107.

Healy, P.M. dan K.G. Palepu. 1993. The Effect of Firms' Financial Disclosure Strategies on Stock Prices. Accounting Horizons, Maret, Vol. 7 No. 1: 1-11.

Holthausen, R.W., D. Larcker, dan R. Sloan. 1995. Annual Bonus Schemes and Manipulation of Earnings: Additional Evidence on Bonus Plans and Income Management. Journal of Accounting and Economics: 29-74.

Ikatan Akuntan Indonesia. 2009. Pernyataan Standar Akuntansi Keuangan No. 53. Standar Akuntansi Keuangan. Penerbit Salemba, Jakarta.

Jensen, M. dan W.H. Meckling. 1976. Theory of The Firm: Managerial Behavior, Agency Costs, And Ownership Structure. Journal of Financial Economics 3: 305-360.

Jiraporn, P., G. Miller, S.S. Yoon, dan Y.S. Kim. 2008. Is Earnings Management Opportunistic or Beneficial? An Agency Theory Perspective. International Review of Financial Analysis, Vol. 17: 622-634.

Johnston-Wilson, D. 2003. Managing Stock-Option Expense: The Manipulation of Option-Pricing Model Assumptions. Working Paper.

Jones, J.J. 1991. Earnings Management During Import Relief Investigation. Journal of Accounting Research (Autumn): 193-228.

Knoll, M.S. 2009. Samuel Zell, The Chicago Tribune, and the Emergence of the S ESOP: Understanding the Tax Advantages and Disadvantages of S ESOPs. Ohio State Law Journal, Vol. 70: 519.

Libby, R. dan N. Seybert. 2009. Behavioral Studies of the Effects of Regulation of Earnings Management and Accounting Choice. Accountancy, Organizations, and Institutions: Essays for Anthony Hopwood Oxford University Press, Johnson School Research Paper Series No. \# 16-09.

Lie, E. 2004. On the Timing of CEO Stock Option Awards. Working Paper.

Uji Pengelolaan Laba Selama Vesting Period (Nur Fadjrih Asyik) 
Machfoedz, M. 2002. Akuntan dan Akuntansi Menghadapi Perubahan Paradikma Bisnis. Surviving Strategies to Cope with the Future. Proceeding Simposium Nasional Bidang Ilmu Ekonomi, Akuntansi, dan Manajemen. Penerbit Universitas Atma Jaya Jogjakarta.

Misnen, A. 2004. Pengaruh Variabel Keuangan terhadap Return Awal dan Return 15 Hari Setelah IPO serta Moderasi Besaran Perusahaan terhadap Hubungan antara Variabel Keuangan dengan Return Awal dan Return 15 Hari setelah IPO di Bursa Efek Jakarta. Jurnal Riset Akuntansi Indonesia, 7: 125-153.

Naim, A. dan J. Hartono. 1996. The Effect of Antitrust Investigations on the Management of Earnings: A Further Empirical Test of Political-Cost Hypotheses. Kelola 13/V/1996: 126-141.

Prawitt, D.F., J.L. Smith, dan D.A. Wood. 2009. Internal Audit Quality and Earnings Management. The Accounting Review Vol. 84 No. 4: 1255-1280.

Scott, W.R. 2009. Financial Accounting Theory. Prentice - Hall International, Inc. New Jersey.

Sesil, J.C., M.K. Kroumova, J. Blasi, dan D.L. Kruse. 2002. Broad-Based Employee Stock Option in US New Economy Firms. British Journal of Industrial Relations, Vol. 40: 273-294.

Simpson, R.H. 1969. An Empirical Study of Possible Income Manipulation. Accounting Review (October): 806-818.

Subramanyam, K.R. 1996. The Pricing of Discretionary Accruals. Journal of Accounting and Economics 22: 249-281.

Watts, R.L. dan J.L. Zimmerman. 1986. Positive Accounting Theory. Englewood Cliffs, NJ: Prentice Hall.

. 1990. Positive Accounting Theory: A Ten Years Perspective. Accounting Review, 65: 131-156.

Yermack, D. 1997. Good Timing: CEO Stock Option Awards and Company News Announcements. Journal of Finance 52 (Juni): 449-476.

Yu, F. 2008. Analyst Coverage and Earnings Management. Journal of Financial Economics, Vol. 88: 245-271. 